\title{
Regimes of social cohesion: converging and diverging trends
}

\author{
Andy Green, Germ Janmaat and Helen Cheng \\ Institute of Education, University of London. ${ }^{1}$
}

\begin{abstract}
Social theorists frequently argue that social cohesion is under threat in developed societies from the multiple pressures of globalisation. This article seeks to test this hypothesis through examining the trends across countries and regions in key indicators of social cohesion, including social and political trust, tolerance and perceptions of conflict. It finds ample evidence of long-term declines in cohesion in many countries, not least as exemplified by the erosion of social and political trust, which is particularly dramatic in the UK. The trends are not entirely convergent, since on most indicators Nordic countries has become more cohesive, yet each country faces challenges. In the final section the authors argue that different 'regimes of social cohesion' can be identified in specific clusters of countries which are based on different cultural and institutional foundations. In the 'liberal model', which applies in the UK and the US, the greatest threat to cohesion comes not from increasing cultural diversity, but from increasing barriers to mobility and the subsequent atrophy of faith in individual opportunity and meritocratic rewards - precisely those beliefs which have traditionally held liberal societies together.
\end{abstract}

\section{Introduction}

This article reviews the state of social cohesion across a range of developed countries at the beginning of the second millennium. Social cohesion is defined in broad and non-normative terms as 'the property by which whole societies, and the individuals within them, are bound together through the action of specific attitudes, behaviours, rules and institutions which rely on consensus rather than pure coercion' (see Green and Janmaat, forthcoming). We explore a number of questions. What are the recent and long-term (post-1980) trends in different countries and regions on the key aspects and measures of social cohesion? Are they

\footnotetext{
${ }^{1}$ This work was supported by the Economic and Social Research Council [grant number RES-594-28-0001].
} 
converging or diverging? Do countries face similar or different pressures on the social fabric in the face of the economic crisis? Do some of us live in a 'broken society' - as Prime Minister David Cameron once described the UK - or are the bonds which bind societies still holding?

We start in Section 2 by summarising some of the macro social theories concerning the impacts of social change on societal cohesion. These generally predict, for a variety of reasons, the increasing atomization of societies and a secular decline in social solidarity across the developed countries. In Sections 3-4 we put these theories to the test, examining in some detail the trends across different countries and regions for key indicators of social cohesion, such as social and political trust, tolerance and perceptions of social conflict. Although confirming the general picture of declining social cohesion these trends shows patterns of divergence as well as convergence across regions (and country clusters). In Section 5 we posit the existence of different 'regimes of social cohesion', each resting on somewhat different cultural and institutional foundations, and suggest that these are vulnerable at different points to the various pressures of globalisation.

\section{Theories of social change and its impacts on Social Cohesion}

Contemporary macro social theories tend to equate globalisation with the general erosion of societal bonds at the national level. Social cohesion is undermined, they claim, by a variety of social trends, including the erosion of national/state identities, the rise of individualism and increasing structural inequalities in societies. These forces are seen to impact on all developed societies, and increasingly on the developing countries most affected by globalisation.

To Castells, a leading theorist of globalisation, the weakening of the nation state undermined by the global forces of transnational capitalism, cross-border crime, and spaceshrinking modern communications - poses a major challenge to social cohesion. The national state, and the collective state identities which it has fostered, were historically among the chief foundations of social cohesion - at least within states, if often not between them (and it is the intra-state dimension that social cohesion addresses). As the power and legitimacy of states has waned, individual and collective identification as state citizens has weakened, removing one of the primary social bonds. With increasing social and cultural diversification, 
and the modern communication technologies which give voice to it, individuals have ceased to identify with the national collective, replacing their loyalty to the state with cosmopolitan supra-national loyalties or more localised or circumscribed identities based on ethnicity, region, religion and lifestyle. To Castells, this 'dissolution of shared identities, which is tantamount to the dissolution of society as a meaningful social system, may well be the state of affairs of our time.' (Castells, 1997, 355).

Identity theorists have come to similar conclusions. Beck $(1999,2004)$ jettisons the nation state as a 'zombie category', castigating those who still think within its parameters as 'methodological nationalists' who hang on to a conceptual framework which is now utterly obsolete. Both he and Giddens (1991), in the latter's theory of 'reflective modernisation', have written of the increasing 'individuation of society', where individual life projects, involving multiple and shifting loyalties and identities, become the focus of identity formation. Touraine (2000), likewise, sees modern advanced societies as experiencing both a secular the decline in the national bonds of citizenship and a rise in communitarian allegiances. '[T]here are more and more identity-based grouping and associations, sects, cults and nationalisms based on a common sense of belonging, and ...they are becoming stronger.' (ibid, 2). Globalisation and localisation combine pincer-wise to squeeze out identification with the national collective. With national society dead, we look to the personal life project for solutions. 'In a world of permanent and uncontrollable change,' he writes,' 'the individual attempt to transform lived experiences into the construction of the self as an actor is the only stable point of reference.' (ibid, 11).

Castells, and other writers on globalisation such as Stiglitz $(2004 ; 2010)$, also frequently note the growing structural inequalities in societies and see these as undermining social cohesion. The recent phase of globalisation has been accompanied by a massive increase in economic inequalities, not only between the richest and poorest countries but also within countries (Wade, 2001). According to one historical estimate, whilst the wealthiest 20 per cent of world population were three times richer than the poorest 20 per cent in the mid-nineteenth century, the ratio by the turn of the twentieth century was a staggering 86 to 1 (Martin and Schumann, 1996). Most developed countries have experienced widening gaps in household incomes and wealth internally during the past 30 years (Esping-Andersen, 2005). Income distribution has become more unequal partly because of the effects of the global division of labour and skillsbiased technological change. As technology has raised the demands for skills in most jobs in developed countries, those with less education and fewer skills have found themselves at a 
disadvantage in the labour market. Competition from low-wage developing countries, combined with the weakening of trade unions bargaining power in some developed countries, has driven down wages for less skilled jobs in the developed countries, thus pulling out the wage distribution at the bottom. (Hutton, 2002; Thurow, 1996). At the same time wages at the very top have escalated as the corporate elites have exploited the relaxed attitudes towards extreme financial rewards which have prevailed in many countries, as well the new possibilities hiking remuneration packages through new instruments such as bonuses, stock options, and tax-avoidance schemes. Wealth inequalities have also soared in many countries, not only because of the massive gaps in pay, but because of the opportunities for further wealth accumulation for those with capital from investment in property assets whose values have constantly inflated (Stiglitz, 2004; 2010).

Increasing inequality has been linked with a multitude of social ills, including lower levels of public health; higher rates of crime, mental illness and depression; and lower levels of selfreported well-being and happiness (Wilkinson and Pickett, 2009). Extreme inequalities, of course, also produce the potential for civil conflict, particularly when the resources to be distributed are diminished. As we have recently seen in the aftermath of the financial crisis and global economic recession, where countries are faced with years of austerity while governments pay back the debts incurred in bailing out the banks, sharp conflicts can emerge over how the pain is distributed. However, the effects of extreme inequality on social cohesion can also be more subtle and insidious.

Inequality increases the social distance between groups, undermining inter-group trust and reducing the sense of common citizenship. As Reich has argued with respect to the USA, with growing income and wealth gaps disparate sections in society no longer feel they have a common interest and a mutual responsibility for each other. They are no longer members of the same society. At the extreme, as in the USA, the rich begin to secede from the public realm altogether. Ensconced in their semi-autonomous and privately-policed 'gated communities', they eschew the public services on which the rest of society depend, and become oblivious to the way most people live. At the same time, the poor are increasingly marginalised from society; excluded by their inability to find work, or by their meagre pay, from buying housing or healthcare; unable to access decent schools; and in many cases forced into urban ghettoes where they interact only with others in similarly deprived conditions (Hutton, 2002; Reich, 2001). 
Large income gaps are quite easily transformed into even larger wealth gaps (Dorling, 2009). These lock in social disadvantage over generations and curtail social mobility. As research has repeatedly shown (Esping-Andersen, 2005), the most unequal societies are usually those, like the US and the UK, with relatively low levels of social mobility. The greater the pay gaps, the less chance of movement between classes since there is so much further to travel between them. Wealth inequality, as Durkheim (1964) noted, can often be more damaging to social cohesion than income inequality, particularly where many individuals appear to derive their wealth from inheritance or asset price inflation rather than through ability and hard work. Incomes tend to rise and fall during different phases of the lifecycle so that people on low incomes at particular points in their lives can take comfort from the hope that better times are around the corner. Capital seems to have more permanence, and because most of it is inherited, not earned, it locks in inequalities across generations (Dorling, 2009). The lack of it can act as a long-term exclusionary mechanism, as in countries where housing is so expensive relative to incomes that lack of capital that becomes the main barrier to home ownership. Likewise social immobility can do more to undermine social cohesion than income inequality, since it gradually erodes the belief in meritocracy and just rewards that is at the heart of the social contract, particularly in the liberal states.

Another growing divide in advanced societies, according to Willetts (2010), is that between generations. A sizeable proportion of the so-called 'baby-boomer' generation - those born roughly between 1940 and 1965 in the West - were lucky. Many of them who started work in the sixties benefitted from plentiful jobs and rising incomes, particularly at the lower end. They, and the boomers who came after, bought properties when they were still affordable, saw their wealth increase dramatically as housing prices rose, and looked forward to retiring at 60 or 65 with generous company pensions based on their final salaries. They had smaller families than their parents' generation and this, combined with their much higher, often dual, incomes, allowed vastly greater household consumption (Willetts, 2010). They were a large cohort and commanded considerable political power, the strength of their 'grey' vote later ensuring few governments would dare challenge the advantages they received from the inflation of their housing assets or from generous public health care they received when they were older.

Many members of the generations that succeeded them were less lucky. With birth rates declining in most countries, they were less numerous and had less electoral clout. They benefitted from rising incomes but were born too late to claim the windfall from the housing 
boom enjoyed by their parents. The latest generation will be the worst off, according to Willets (2010). In most countries those leaving education now will find it hard to get jobs, and the jobs they do get will be less secure. Graduates must often pay back substantial student loans and are unlikely to see the same return to graduate qualifications as previous generations. They will find it hard to afford to buy a house and even those who can are unlikely ever to pay off their mortgages. They will effectively be permanent renters of their properties from their loan companies. But at least they will be more secure that those renting in the private market or relying on the much reduced stocks of social housing. And all of them will be paying the higher taxes necessary to pay off the vast public debts incurred by governments bailing out the bankers of previous generations. They will no doubt have to work until they are 70 and will rarely receive the generous company pensions enjoyed by their parents - for which, in many countries, the young have been paying through their taxes or pension contributions. In many countries, for the generation reaching maturity now, their prospects relative to those of their parents' generation are arguably worse than those for any generation since the one that went to fight in the First World War. Of course, some will be better off than others, depending on what they have inherited from their parents, and the advantages they have received from their education. But the potential for conflict between generations has never been greater.

\section{Convergence or Divergence?}

These general theories posit universal shifts. They argue that secular changes are occurring in the fundamental structures of all advanced societies and assume that these are more or less convergent - or at the least uni-directional - trends. But how far does the empirical evidence support this thesis? We look here at long-term trends in measures of social trust, political trust, tolerance and perceptions of conflict between groups.

Trust

Interpersonal or 'social' trust has often been considered one of the key measures of social cohesion (Green, Preston and Janmaat, 2006; Reeskens, 2007; Uslaner, 2002;). It relates to people's willingness to place their confidence in a wide range of others, including people they do not know. And it is widely considered to be an important precondition for the functioning of modern societies where a highly evolved division of labour means that 
everyday activities often involve interactions with strangers. Trust is necessary for the legitimacy of democratic systems which require that we trust the politicians we elect to deliver their pledges. It is also a precondition for welfare states which redistribute resources towards the needy because they depend on people trusting that if they pay their taxes to support others in need, these will not abuse the system, and others in turn will pay theirs to support them if they are in need (Canovan, 1996). Trust is also essential for efficient economic activity which depends on people sticking to what they have agreed and performing their contracts. The higher the levels of trust and trustworthiness the less the need for legal contracts and lawyers for every transaction and thus the lower are transaction costs (North, 1990). Above all, trust is what allows people to go about their daily business without constant fear of being let down or cheated. This general form of trust has been widely identified as necessary for a substantial range of private and public goods in society. If we believe the correlational evidence, it is closely associated with economic and social outcomes as diverse as economic growth (Knack and Keefer, 1997), innovation (Osberg, 2003), public health (Wilkinson, 1996), better government (Putnam, 2000) and general well-being and happiness (Wilkinson and Pickett, 2009).

Social trust is usually measured by the survey question which asks: 'Generally speaking, would you say that most people can be trusted or that you can't be too careful in dealing with people?' It can be objected that the question is not entirely clear about the range of people in question, but factor analysis suggests that respondents do indeed interpret the question in terms of how much they trust strangers (Uslaner, 2002). Other statistical tests also suggest that the measure is relatively robust. For instance, 'Dropped wallet' experiments conducted in different countries show that in countries with high levels of measured trust more of these wallets are returned. There is also a strong correlation between measured levels of trust in particular countries and the perception of foreigners as to how far people can be trusted in these countries, suggesting that trust and perceptions of trustworthiness are closely related (Green, Preston and Janmaat, 2006). Results from repeated surveys in different countries over 50 years do show considerable consistency in the international patterns of trust. There are very large differences between countries in how far people say they trust each other and these differences remain relatively stable over time.

We know relatively little about how trust arises. Putnam has argued (2000) that trust derives from participation in groups; that it arises out of the repeated interactions between individuals in associations bound by collective norms. We learn to trust through successful cooperation 
with others in pursuing common objectives. He supports this with evidence from the US that people who join associations are more likely to be trusting. However, as others have shown, this correlation does not hold in all countries (Newton, 1999), let alone across countries (Green et al, 2006; Uslaner, 2002). There is no significant relationship between levels of trust in a country and the frequency with which its people join organisations. Even if the US data do show a correlation between trust and association, Putnam is unable to show which way the causality runs. It may well be that it is because people trust that they are more willing to join associations, rather than the other way around.

Uslaner (2002) provides a more nuanced analysis of the nature of trust. He distinguishes between 'strategic trust', which depends on a calculation of whether given others are trustworthy, and 'moral trust,' which is based on fundamental character traits, such as optimism and 'sense of control,' which encourage people to believe that people should be trusted. The first is contingent and subject to change depending on the context and the experience of the others in question. The second does not depend so much on social context and experience and is more stable over time. Moral trust, he says, is learnt early on in life from parents and will be relatively enduring. 'Collectively,' he writes, 'the most optimistic person - who wants a fulfilling job, thinks about the future, and believes that she can make it regardless of luck, connections, or current circumstances - is 36 percent more likely to trust others than the most convinced pessimist.' (Uslaner, 2002, 13).

Research from the field of psychology provides some evidence to confirm the conjecture that early childhood experiences have a significant influence on adult trust. Studies using UK longitudinal datasets such as the National Child Development Study (NCDS) and the British Cohort Study (BCS70) find that levels of adult political trust are predicted to some extent by parental class at birth and intelligence measured during childhood (Deary et al, 2008; Schoon et al, 2010; Sturgis et al, 2010). In another study based on these datasets Schoon and Cheng (in press) also found a significant association between school motivation at teen age and political trust in early adulthood in both NCDS and BCS70 cohorts born in 1958 and 1970 $(\mathrm{r}=.23$ in NCDS and $\mathrm{r}=.24$ in BCS70, $\mathrm{p}<.001)$. In our own recent work we have looked at the associations between family social class, childhood and teenage emotional disorder, and adult social trust in the British cohort studies NCDS and BCS70. As can be seen from Table 1, both parental social class and early emotional disorder tended to influence adult social trust in an expected direction: participants from higher social class families tend to score higher on social trust in their early adulthood; participants' childhood and teenage emotional 
Table 1. Pearson correlations among parental social class, childhood and teenage emotional disorder, and adult social trust in NCDS and BCS70

\begin{tabular}{|c|c|c|c|c|c|c|}
\hline \multicolumn{7}{|c|}{$\operatorname{NCDS}(N=8,663)$} \\
\hline Variables & & Gender & $\begin{array}{l}\text { Parental } \\
\text { social } \\
\text { class }\end{array}$ & $\begin{array}{l}\text { Emotional } \\
\text { disorder } \\
\text { (age 11) }\end{array}$ & $\begin{array}{l}\text { Emotional } \\
\text { disorder } \\
\text { (age 16) }\end{array}$ & $\begin{array}{l}\text { Social trust } \\
\text { (age 33) }\end{array}$ \\
\hline Gender & $\begin{array}{l}.51 \\
(.50)\end{array}$ & - & & & & \\
\hline $\begin{array}{l}\text { Parental } \\
\text { social class }\end{array}$ & $\begin{array}{l}3.22 \\
(1.21)\end{array}$ & $-.25^{*}$ & - & & & \\
\hline $\begin{array}{l}\text { Emotional } \\
\text { disorder } \\
\text { (age } 11)\end{array}$ & $\begin{array}{l}1.50 \\
(1.34)\end{array}$ & $.030 *$ & .005 & - & & \\
\hline $\begin{array}{l}\text { Emotional } \\
\text { disorder } \\
\text { (age 16) }\end{array}$ & $\begin{array}{l}.88 \\
(1.14)\end{array}$ & $.153 * * *$ & .004 & $.369 * * *$ & - & \\
\hline $\begin{array}{l}\text { Social trust } \\
\text { (age } 33 \text { ) }\end{array}$ & $\begin{array}{l}2.75 \\
(0.68)\end{array}$ & $.067 * * *$ & $.057 * * *$ & $-.032 * * *$ & $-.039 * * *$ & - \\
\hline
\end{tabular}

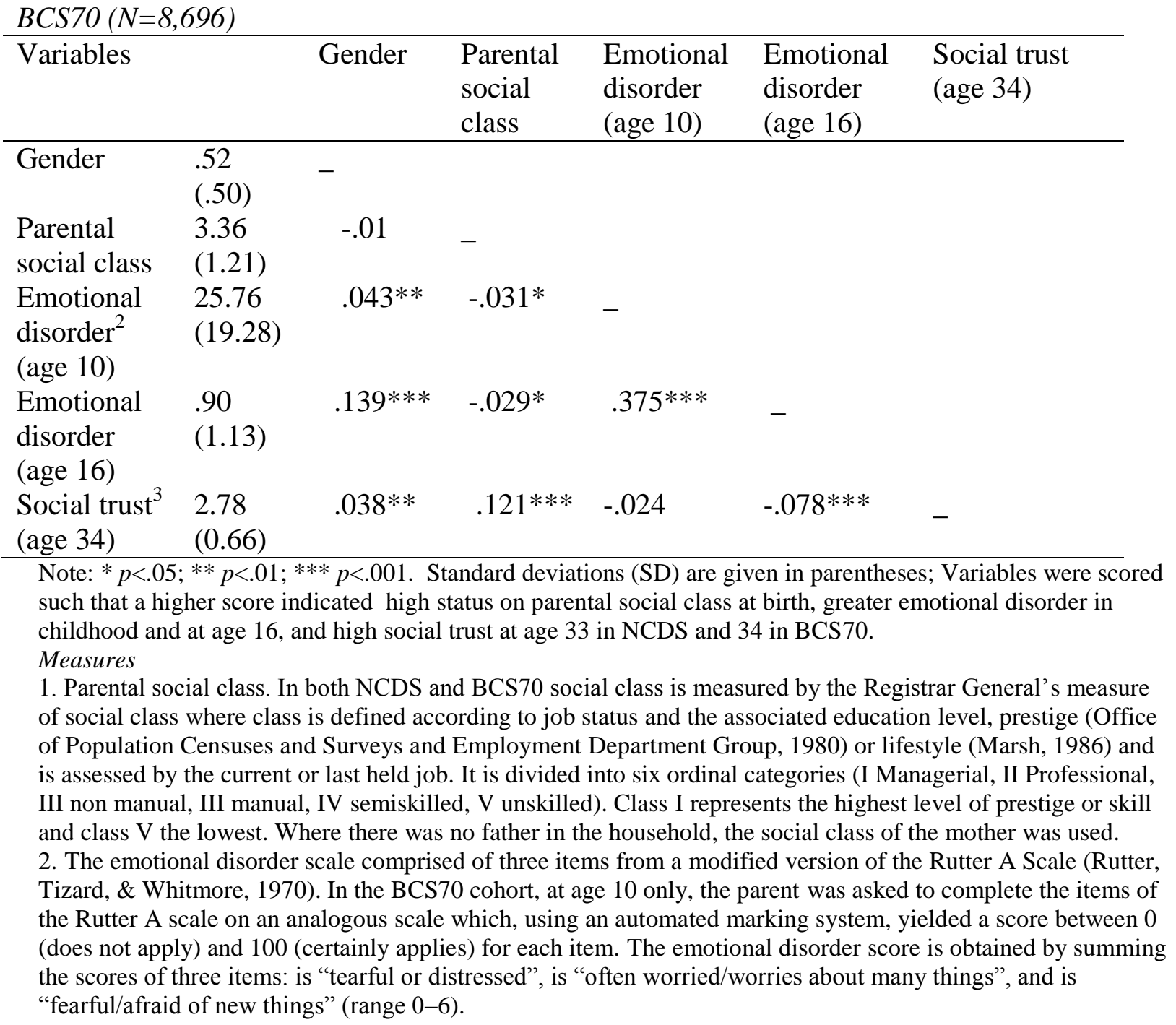


3. Social trust was captured in the NCDS at age 33 with a single-item measure. Cohort members were asked 'Generally speaking, would you say that most people can be trusted or that you can't be too careful in dealing with people?' The item tapping social trust in the BCS70 at age 34 was worded differently. Cohort members were asked "How much do you trust people in your local area?" ( 1 = not at all, 2 = not very much, $3=$ a fair amount, $4=\mathrm{a}$ lot).

disorder tended to have negative effects on their social trust later on. Further, in both cohorts, women had higher scores on social trust in both NCDS and BCS cohorts.

Unfortunately, the UK longitudinal data cannot tell us whether trust remains stable over the life course. NCDS does ask about trust at two points, at 33 and 46 years, but the questions are asked differently and the answers cannot be compared. Uslaner provides some evidence, from a US panel survey conducted in 1965, 1973 and 1982, ${ }^{2}$ which indicates the relative stability of trusting attitudes. On his analysis, almost two thirds of young people and more than 70 percent of their parents were consistent 'trusters' or 'mis-trusters' throughout the very different decades of the 1960s and 1970s. (Uslaner, op cit, P. 10). On the other hand, the data also suggest that context and experience may have altered levels of trust in a third of cases, which could have quite substantial effects on aggregate trends if the changes are mostly in the same direction. Cohort analysis using cross-sectional data doesn't really help us to answer the question either, since we never know whether differences between cohorts at different times are due to period or life cycle or cohort effects. In any case the findings from studies differ. Cross-country data for 1959 provided by Almond and Verba (1963) suggested that older and younger people were equally likely to trust. However, Hall (1999), using data from the repeated waves of the World Values Survey, found that people over 30 years were more trusting in 1981 than people under 30 and that the age differential had increased by 1990.

What we do know - and what must considerably qualify any explanation of trust based purely on the effects of early parenting - is that levels of trust vary massively across countries, from less than ten per cent in Brazil and Turkey, for instance, to over 60 per cent in Norway and Sweden (Delhey and Newton, 2005). Aggregate levels of trust in different countries do change over time, but the patterns across countries show considerable regularity. We also know that average levels of trust tend to vary by social class, with the more affluent more inclined to trust than others lower down the income scale (Hall, 1999). These social variations suggests that although being trusting is an individual disposition, which may well

\footnotetext{
${ }^{2}$ Parent-Child Socialisation study conducted by M. Kent and Richard G. Niemi.
} 
owe in part to deep-seated personality traits, it is also strongly influenced by societal contexts. People are more likely to trust as adults if others are trustworthy. So trust is not only fundamental to the functioning of societies. It is also a product of how societies function.

What the trend data on aggregate levels of social trust in different countries show is quite startling and extremely worrisome from the point of view of social cohesion. Figures 1 and 2, drawn from different data sets, show the trends in aggregate levels of trust between 1981 and 2009. Figure 1, based on World Values Survey data, averages the aggregate levels of trust for countries in a number of country groups, and shows that for three out of five of them - the 'liberal', 'southern European' and 'east Asian' groups - trust declined significantly between 1981 and 2005, while it remained flat in the 'social market' group. ${ }^{3}$ For more recent years we only have data from European Social Survey and Eurobarometer for a small number of countries. These surveys use the same question as the World Values Survey, but, unlike the latter, which demands dichotomous yes or no answers, allow answers on a scale. ${ }^{4}$ Figure 2 , which standardizes the scales, provides values for the period 2002 until 2009 for a few individual countries. In most cases there is a further dramatic decline in levels of trust. Following a period of reasonably stability from 2000 to 2005 , there is a sharp decline in average levels of trust in Germany, Spain, and the UK. Even Sweden shows declining levels of trust after 2008, coinciding with the economic crisis.

\section{Figure 1 Trends in Social Trust (\% most people can be trusted)}

\footnotetext{
${ }^{3}$ In order to avoid the more populous countries dominating the country groups we gave the country aggregate scores equal weight when calculating the group means.

${ }^{4}$ In ESS the item had a 0-10 scale (0 "can't be too careful "---- 10 "most people can be trusted") while in the EB it had a 110 scale (1 "can't be too careful" ---- 10 "most people can be trusted"). To make the answers comparable we subtracted the EB scale with 0.5. As a result, the midpoint in the scale for both the ESS and EB item is 5.
} 


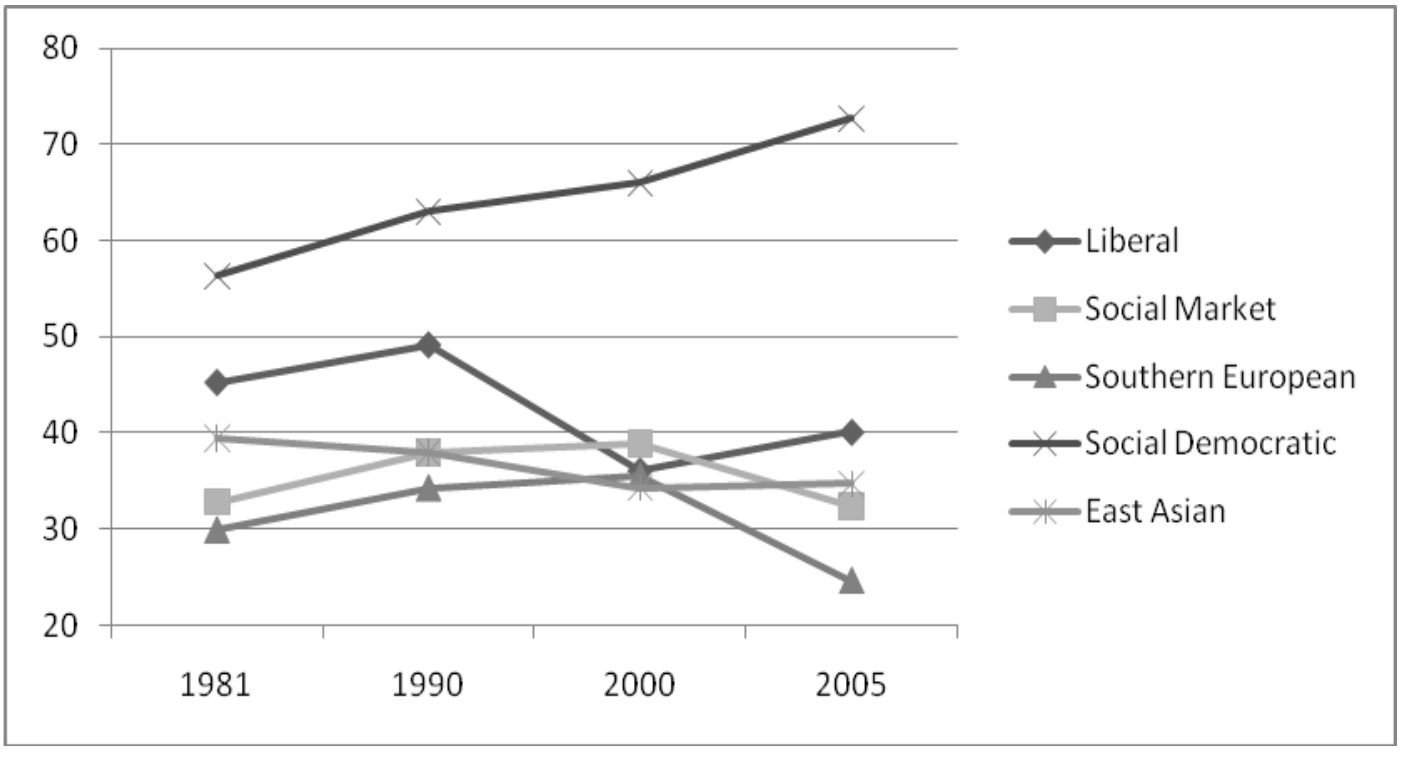

Source: World Values Survey data for 1981, 1990, 2000, 2005. These data can be obtained at http://www.worldvaluessurvey.org/

Note: Our labelling of country groups as liberal, social democratic and was inspired by an historical analysis of the different intellectual traditions of writings on social cohesion in political philosophy, political economy and sociology and also through a critical reading of the contemporary literature on welfare regimes (e.g. EspingAndersen, 1990) and varieties of capitalism (e.g. Hall and Soskice, 2001). Elsewhere we tested whether the regimes and varieties identified by these scholars also applied for social cohesion. Using a variety of techniques such as cluster analysis, composite indicators and factor analysis to explore country clusterings, we indeed found a large overlap between welfare regimes / varieties of capitalism and social cohesion regimes, but we also made some modifications to the country groups (Green et al , 2009). The groups presented here represent these modifications. We distinguish the following groups: a 'Liberal' group, including the UK, the US, Canada and Australia; a 'Social Democratic' group, comprised of Denmark, Sweden and Norway; a 'Social Market' group, including West Germany, France and the Netherlands; a 'Southern European' group, made up of Spain and Italy, and an 'East Asian' group including Japan and South Korea. For Figures 1, 4 and 10-15 we made sure that the country groups comprise these same countries for each point in time.

\section{Figure 2 Trends in Social Trust (mean of 0-10 scale)}




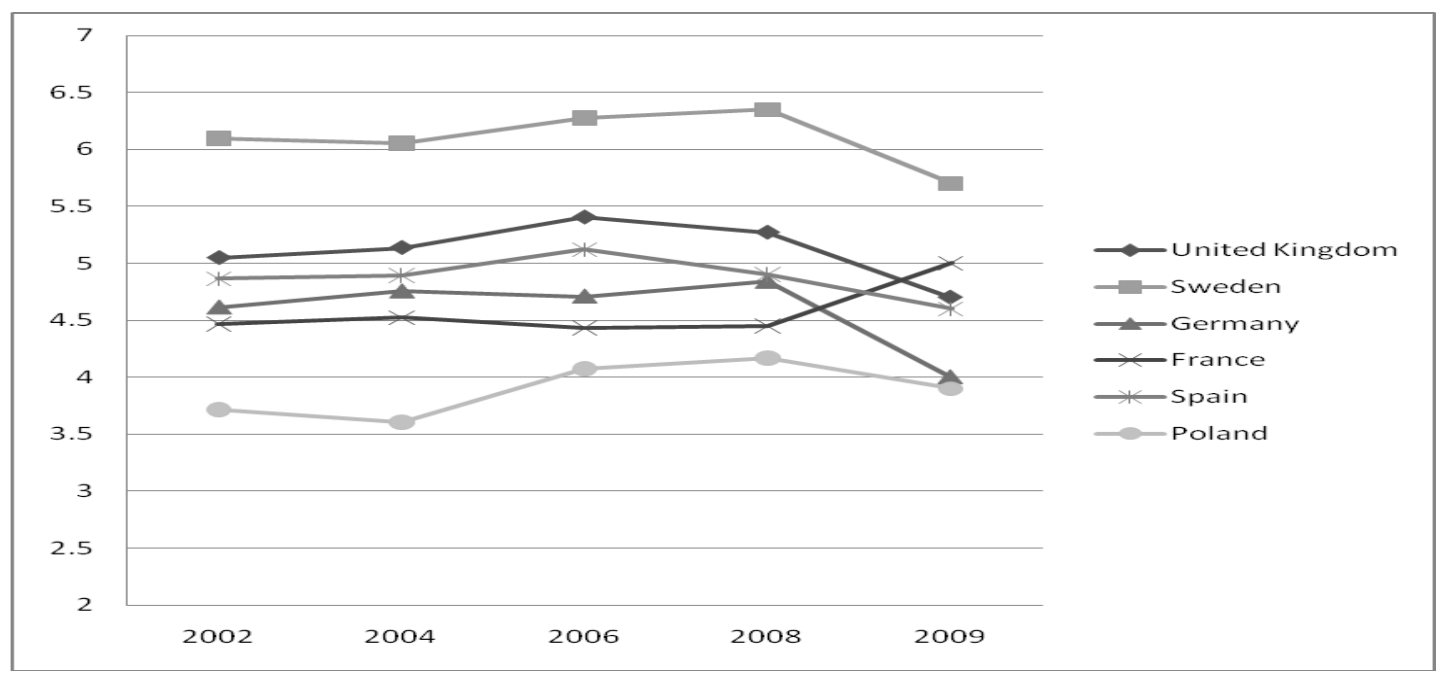

Source: European Social Survey (ESS) rounds 2002, 2004, 2006 and 2008 and the Eurobarometer 72.1 (SeptOct 2009). The ESS data can be obtained at http://www.europeansocialsurvey.org/. The Eurobarometer data can be obtained at http://www.gesis.org/dienstleistungen/daten/recherche-datenzugang/zacat-online-study-catalogue/

We cannot compare the values on the two graphs, since they are based on surveys using different scales, so we cannot say exactly how far trust has declined overall. But what we can see is that there was a general decline in levels of trust (albeit with some fluctuations) in the 24 year period from 1981 to 2005 in the English-speaking and southern European groups of countries and that in certain countries from each group (the UK for the English-speaking countries and Germany and Spain for the continental European countries) this continued over the next decade, although France defies the trend in the final two-year period. The countries with the most severe declines in trust appear to be the US and the UK. If we include in the time series Almond and Verba's (1963) 1959 figures for the UK and the US (Figure 3), again based on comparable survey questions, we can see that trust in the UK dropped catastrophically from just under 60 per cent of people saying they generally trusted others in 1959 to around 30 per cent in 2005 (30.4 percent). The figure for the US dropped from around 60 per cent to just over 40 per cent. $^{5}$

Figure 3. Trends in social trust (percentage saying "most people can be trusted")

\footnotetext{
${ }^{5}$ It could be argued that in order to control for the effect of short term economic fluctuations on trust one should ideally measure long-term trends in trust using points in time when the economy was in similar states (i.e. using either moments of boom or moments of recession). However, data limitations prevented us from doing so. Moreover, it cannot automatically be assumed that trust always declines in periods of recession and always rises in periods of growth. Actually, if an economic fluctuation effect does exist, the long term declines in trust for the liberal and southern European groups recorded in Figure 1 would even become more pronounced as the start of the time series (1981) fell in a period of recession (depressing trust levels) and the end of the time series (2005) marked a period of economic growth (enhancing trust levels).
} 


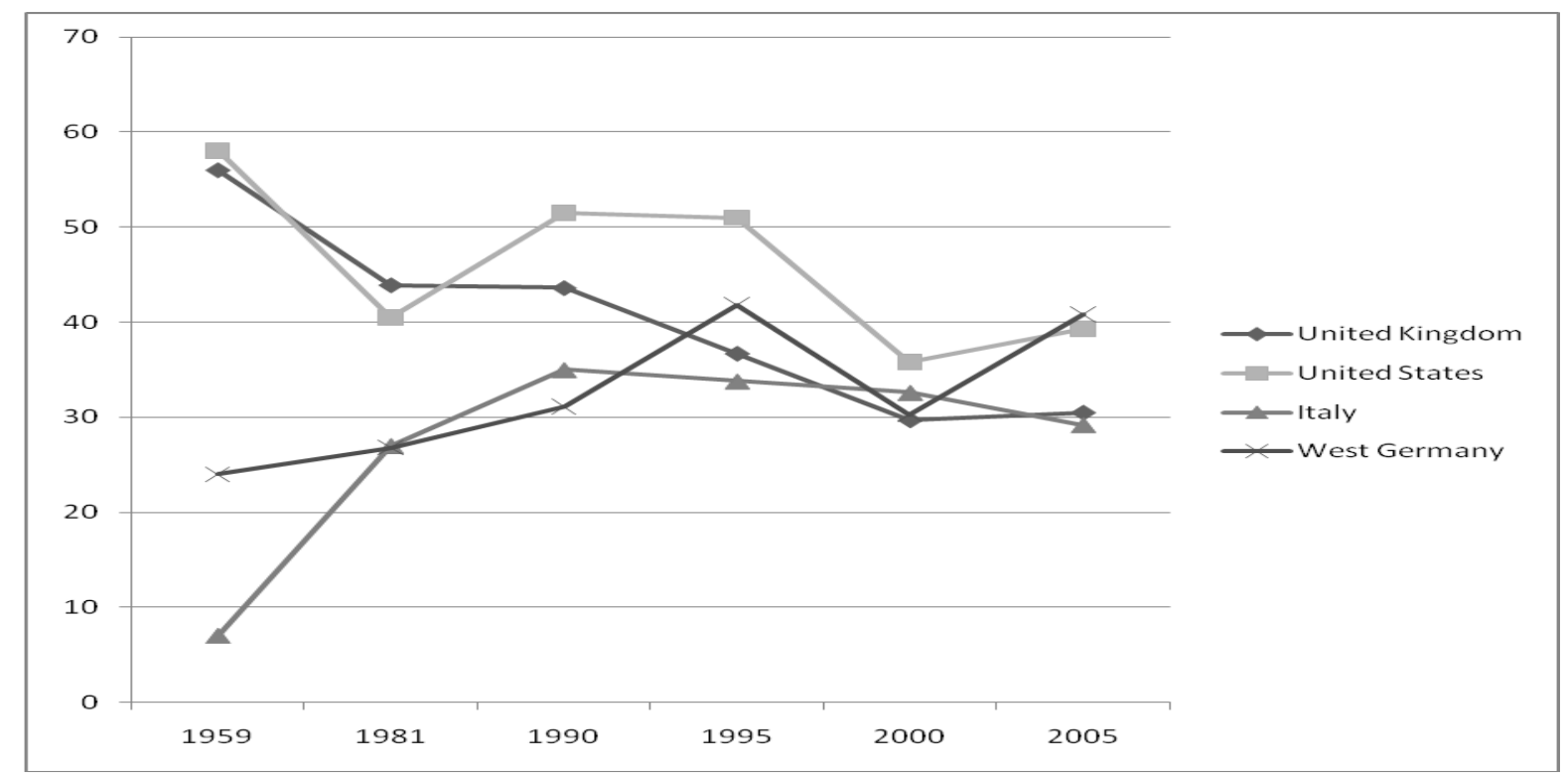

Sources: Almond and Verba (1963); World Values Survey, Waves 1-5 (see footnote to figure 1).

In as much as trust is an important measure for social cohesion, these trends in levels of trust would appear to confirm, at least partially, the general theories discussed above which posit universal and convergent changes in levels of social cohesion. However, there is a major exception. Levels of trust rose significantly in the Nordic group of countries between 1985 and 2005 and continued to rise after this in Sweden until 2008.

The same divergence between the Nordic and other countries also seems to apply with respect to the trends in political trust. Political trust, or trust in (government) institutions, is generally thought to be closely linked to general or interpersonal trust (Delhey and Newton, 2005; Inglehart, 1997; Putnam, 1993; Uslaner, 2002). At the individual level, it may have some common origins in early childhood with general trust, but it is also subject to changes throughout the life course due to learning and experience. Some longitudinal studies find it declines with age (Schoon et al, 2010). But it is most certainly also affected by societal context and, like social trust, varies substantially across countries.

As with social trust, political trust - measured here in terms of confidence in parliament - has declined markedly over the past three decades in many advanced countries. Figure 4 shows large declines in the liberal and social market groups between 1981 and 2005. Figure 5 shows continuing declines after 2001 in Germany, France, Spain and the UK, with the steepest declines after 2008, as one would expect. The major exception again appears to be the Nordic 
countries. The average level of political trust for these countries increased during the 19812005 period, when it was falling in most other countries, and it stabilized in Sweden right until the end of 2009. Sweden thus did not experience the sharp decline in political trust that the other countries did in the year that the crisis kicked in.

Figure 4 Trends in Political Trust (\% very much and quite a lot of confidence in parliament)

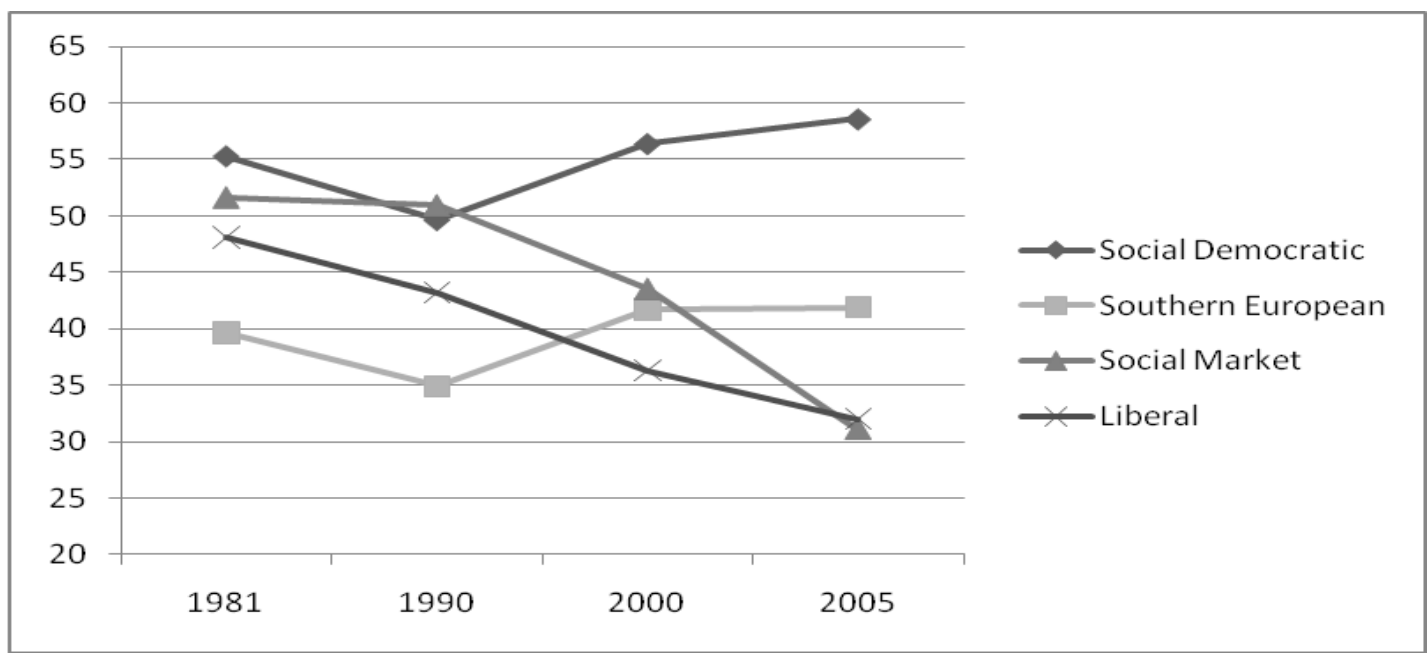

Source: World Values Survey (see notes for Figure 1).

Figure 5 Trends in Political Trust (trust in parliament; mean of 0-10 scale) 


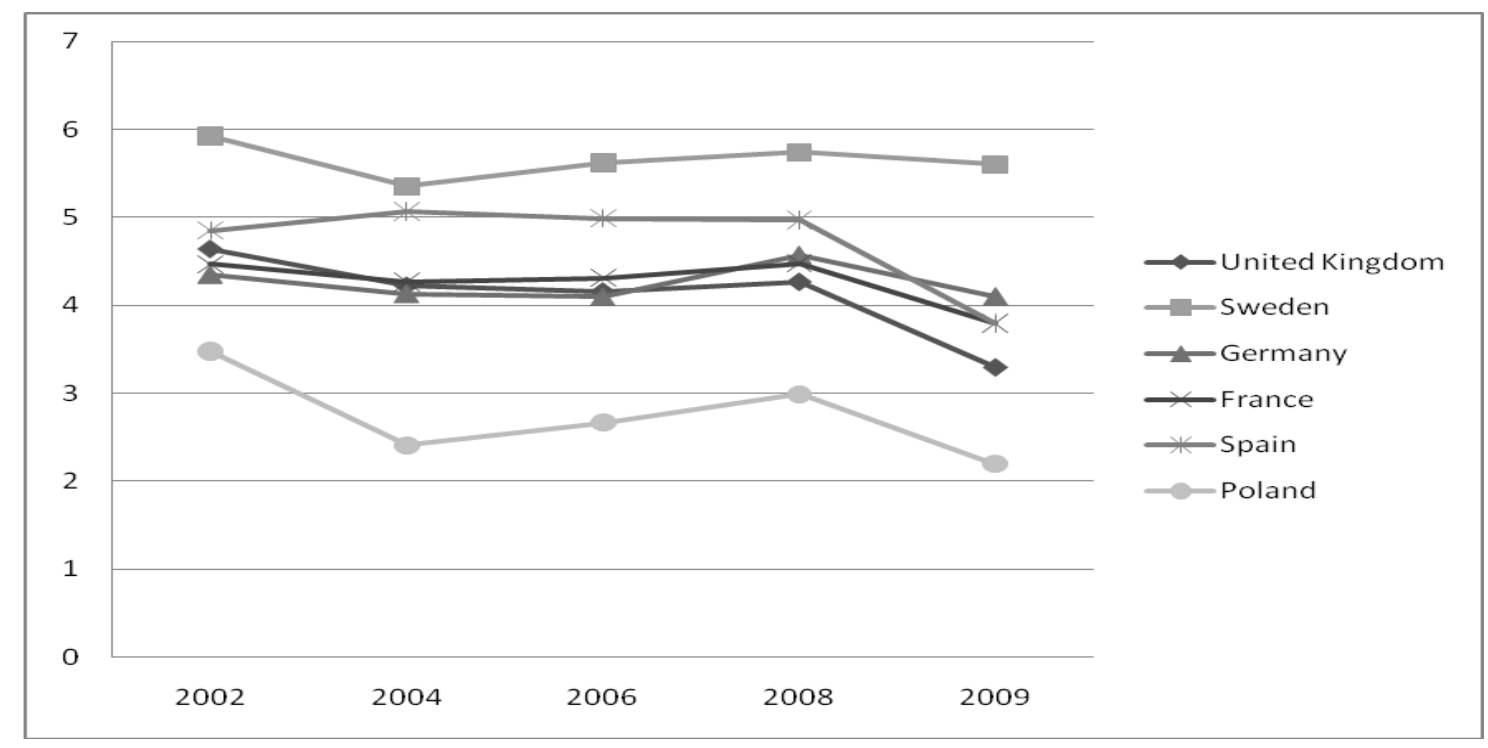

Sources: European Social Survey and Eurobarometer (see notes for Figure 2).

It is also interesting to examine trends in trust by birth cohort as the economic crisis is likely to have affected age groups differently. The young, who are often working in temporary jobs, are much more likely to have lost their jobs than the older generations because cutting back on temporary staff is usually one of the first measures that employers take when confronted with an economic crisis. Because the crisis is likely to have hit the young harder, we would expect them to show the steepest drop in trust. Figures 6 and 7 which are based on the pooled data of the United Kingdom, Sweden, Germany, France and Spain, show that social and political trust have indeed declined most in the younger age groups from 2006 to 2009. Social trust declined in all age groups to levels below the midpoint of the scale (indicating on balance more distrust than trust), but the fall was particularly pronounced in the cohorts born after 1964. Political trust was already at levels below the midpoint of the scale in 2006 and has fallen even further in 2009 in all age groups. Again the younger generations show the most significant drops, particularly those born between 1965 and 1984. In fact, while the younger age groups showed slightly higher levels of both social and political trust in 2006, the correlation was decidedly reversed in 2009 with the older generations exhibiting higher trust levels. ${ }^{6}$

\footnotetext{
${ }^{6}$ It could be argued that these findings are nothing special if attitudes like trust are generally more fluctuating among younger cohorts. However, other research investigating long term trends in social attitudes finds younger and older cohorts to show the same short term variations in attitudes (e.g. Inglehart 1997: famous graph). This further underlines the significance of the current findings.
} 


\section{Figure 6}

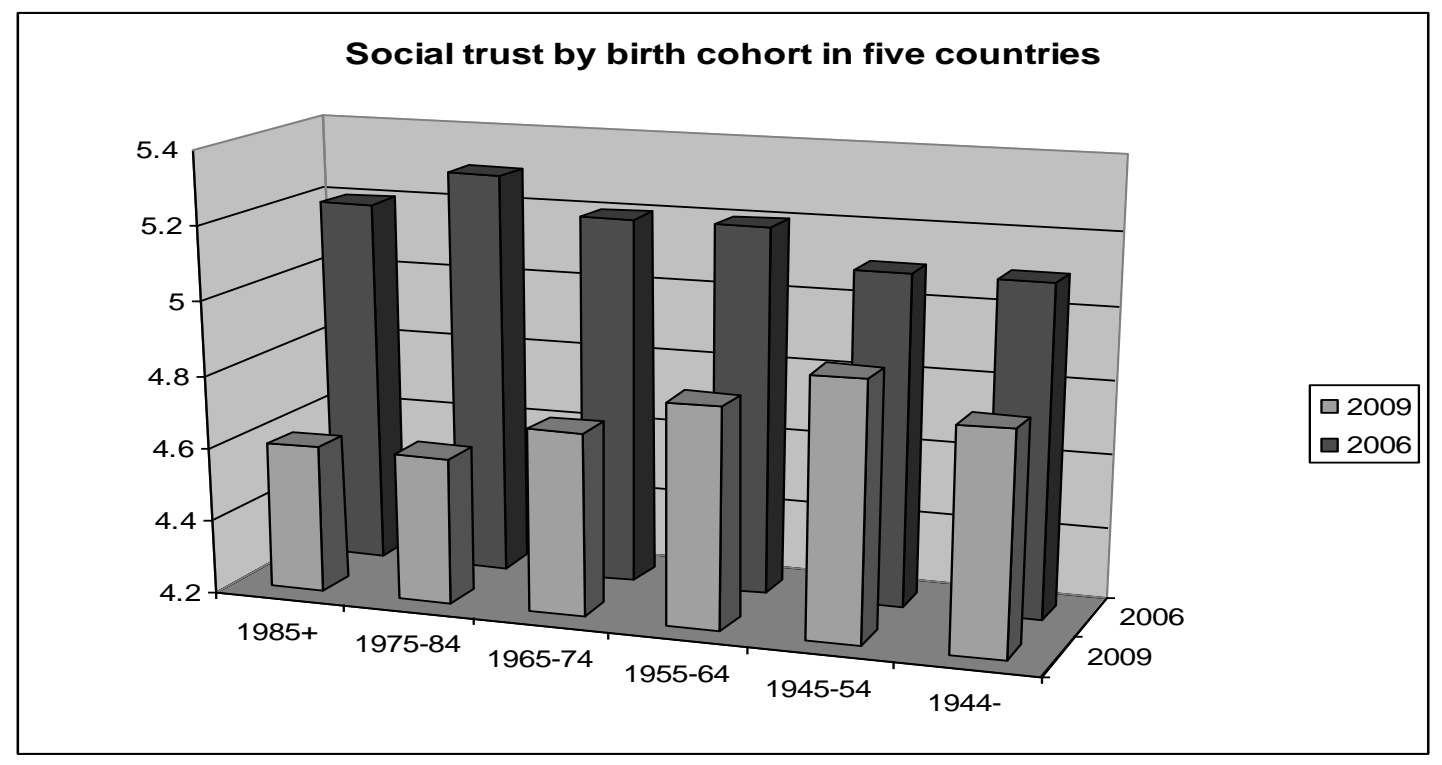

Source: European Social Survey round 2006 and the Eurobarometer (see notes for Figure 2).

However, the pooled data of Figures 6 and 7 is likely to hide important differences between countries. Because of differences in labour market institutions and policies the young in different countries are likely to be affected in different ways by the economic crisis. In the United Kingdom, for instance, with its flexible labour markets, many youngsters with fixed term contracts may have become unemployed but they may have had less difficulty in finding new work. By contrast, in the more regulated labour markets of the social market and southern European countries, where youth unemployment was already at relatively high levels, the crisis is likely to have prolonged the long-term unemployment of youngsters and thus to have given rise to widespread feelings of exclusion and discontent (see also the discussion of the social market regime further below). Figures 8 and 9 indeed show remarkable differences between - in this case - Germany and the United Kingdom. While both social and political trust levels have fallen at practically the same rate in all age groups in the United Kingdom, trust has declined markedly more among the younger cohorts in Germany. Here, political trust among the oldest age group has even increased. 


\section{Figure 7}

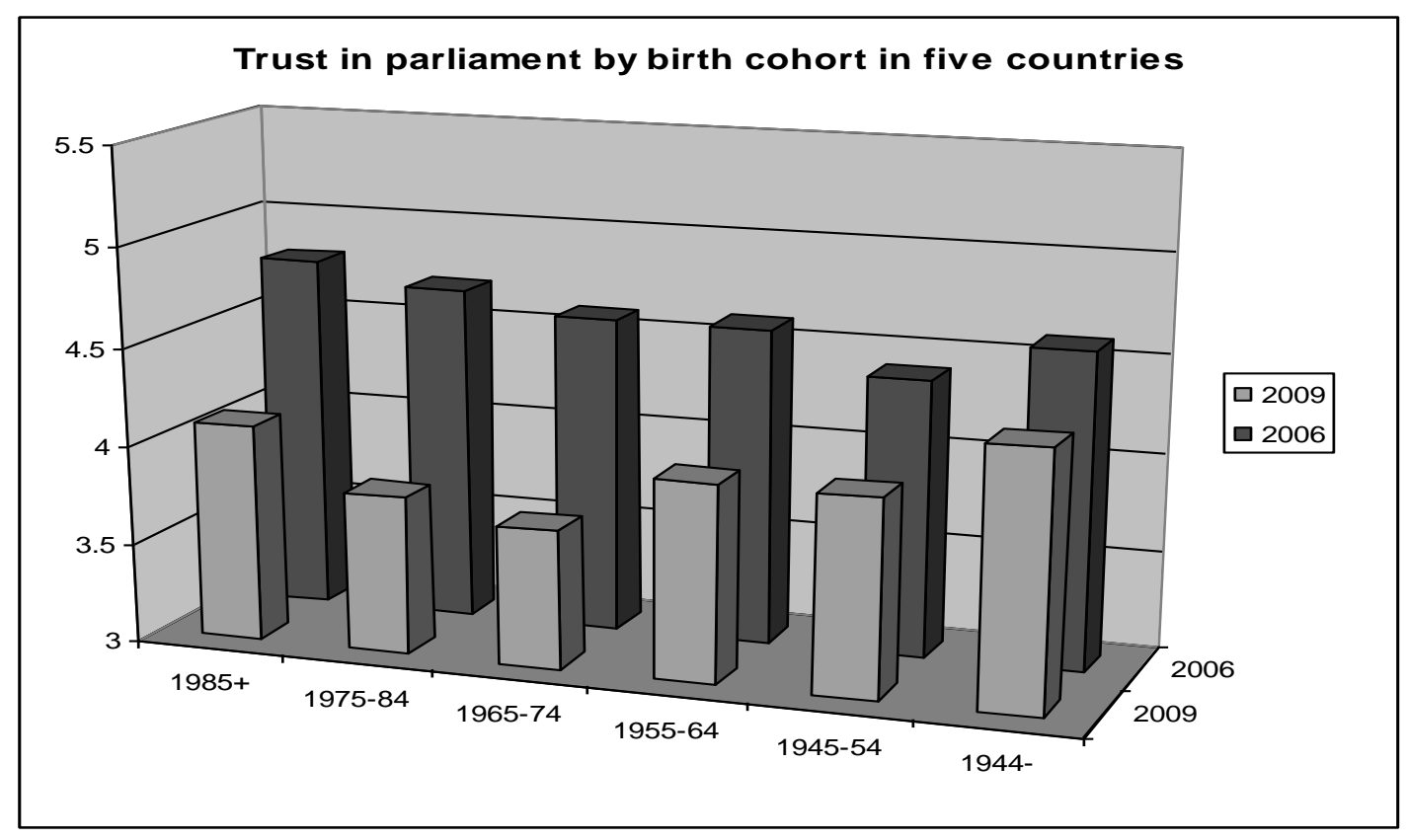

Source: European Social Survey round 2006 and the Eurobarometer (see notes for Figure 2).

\section{Figure 8}
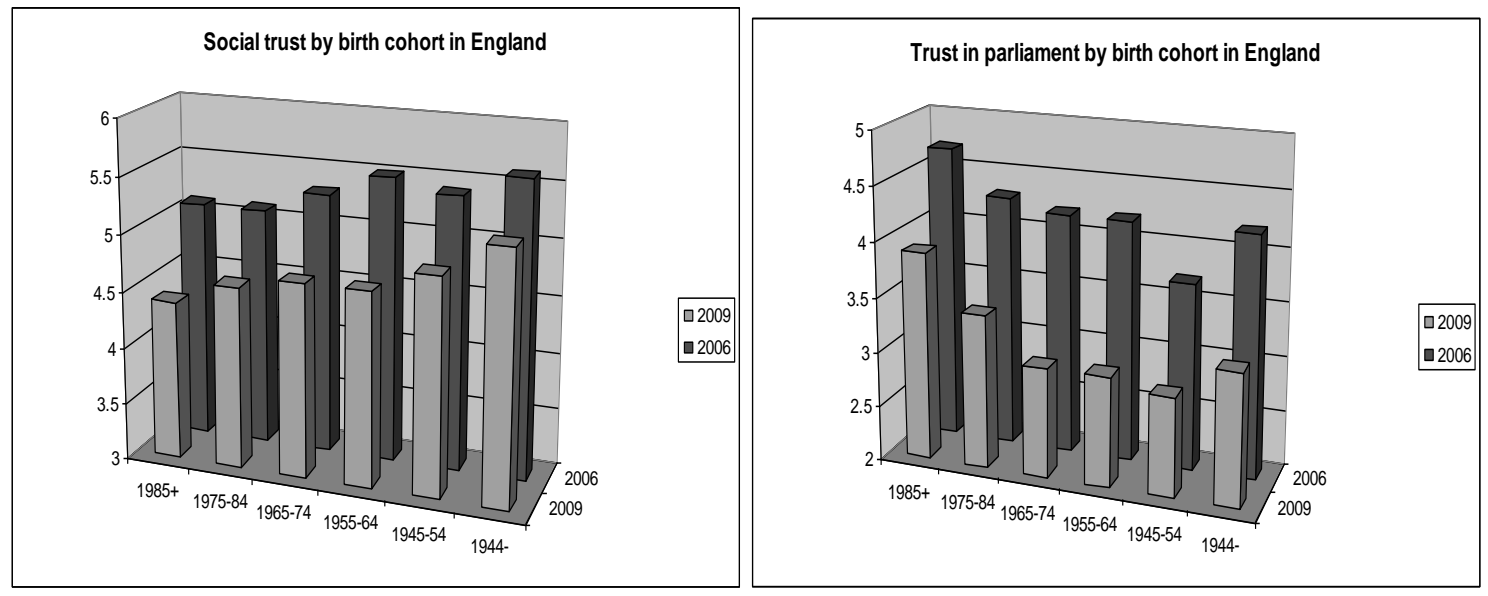


\section{Figure 9}
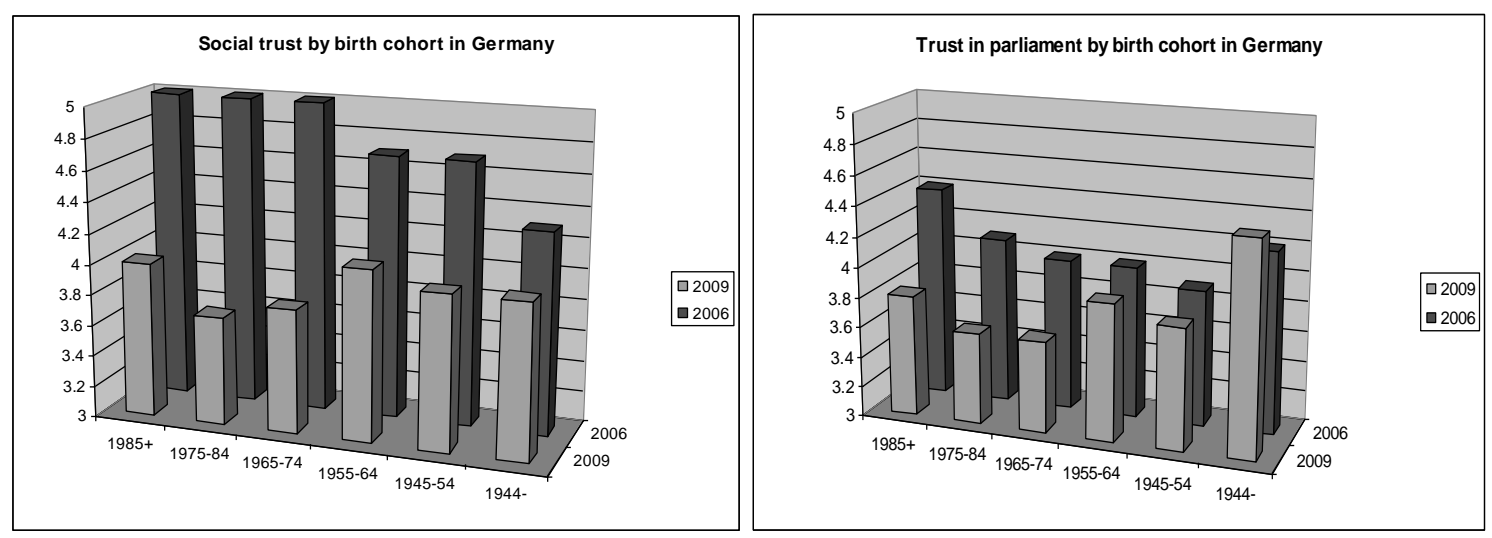

Source: European Social Survey round 2006 and the Eurobarometer (see notes for Figure 2).

\section{Tolerance}

Tolerance is another characteristic often associated with socially cohesive societies, although it has arguably received more emphasis, historically, in liberal political philosophy than in other traditions. The contemporary empirical evidence suggests that it is a highly contextcontingent characteristic, varying considerably by social group within countries, and subject, at the national level, to considerable swings over time (Green, Preston and Janmaat, 2006). Although in some countries tolerance and other measures of social capital seem to go hand in hand at the individual level (Putnam, 2000), this is not true in all countries. Aggregate national levels of trust and tolerance do not co-vary across countries (Green et al, 2006). Nevertheless, for many people tolerance would be considered a sine qua non of social cohesion. The World Values Survey measures tolerance by asking respondents if they mind having immigrants as neighbours. The question might be thought to go pretty close to the heart of the matter, thus providing a fairly good proxy for tolerance. But it only taps attitudes towards immigrants and not towards other minority groups. 
Figure 10 Trends in Tolerance (\% not minding having immigrants as neighbours)

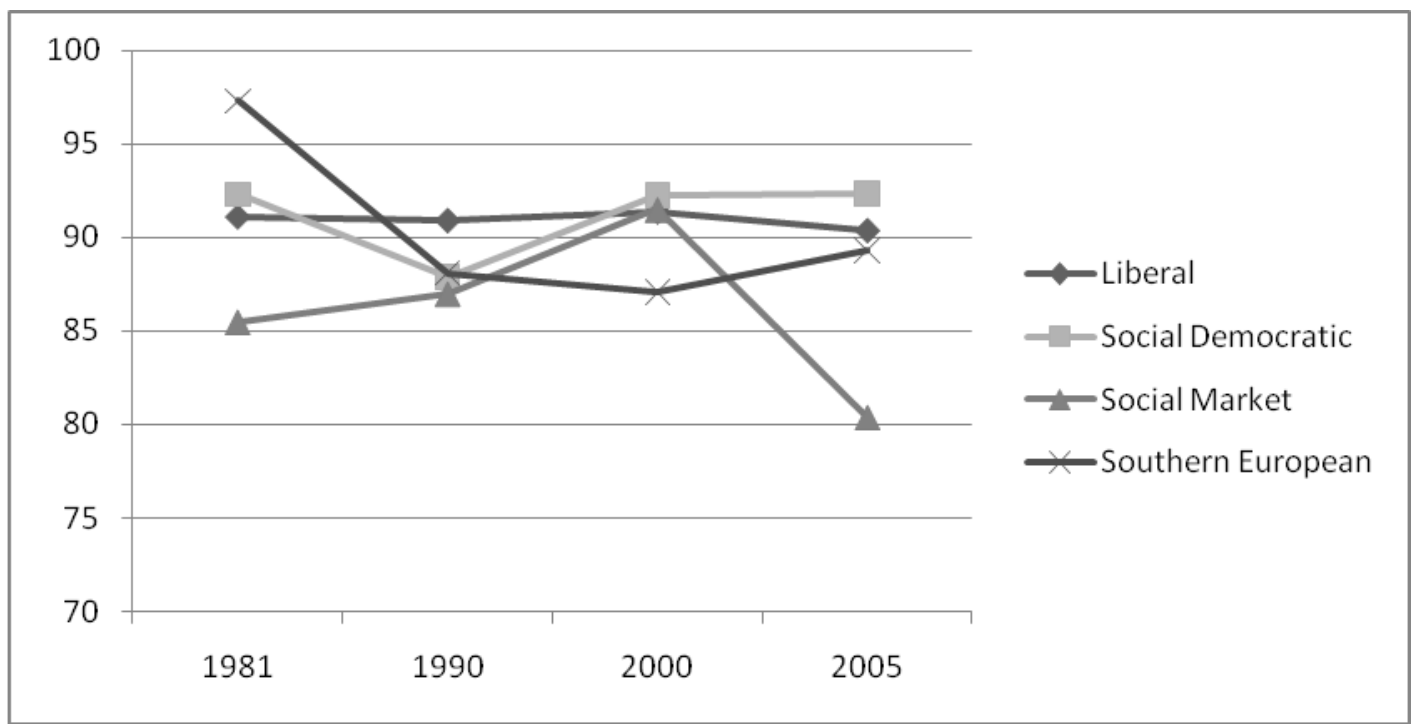

Source: World Values Survey (see notes for Figure 1).

The World Values Survey data shows that the trends on this measure are, indeed, quite country specific. Between 1981 and 2005, tolerance increased substantially in Germany until 2001, before falling off slightly, whereas it declined precipitously in France, particularly after 2001. The US shows a steady but small decline, and likewise the UK, after a small rise in the 80s. Sweden, on the other hand, manifested a decline in tolerance in the 80s but subsequently showed a substantial rise which left levels higher level in 2005 than in 1981. If we average the values for different country groups (see Figure 10), one can see a very slight decline for the liberal group, a sharp decline for the social market group (presumably driven to a considerable extent by France), but a small rise for the social democratic countries, due to the significant increases after the 1980s. Although some variation between countries in each group warns against placing too much stress on the regional patterns, there is some evidence again of divergent trends between the Nordic and other groups of countries.

\section{Conflict}

Another useful measure of social cohesion is the perceived level of tension between different social groups. We have 2009 data from Euro barometer for a sizeable number of countries on perceived tensions between rich and poor, managers and workers, generations and different 
ethnic groups. Figures 11 to 14 show the average for each country group, with the bars showing confidence intervals ${ }^{7}$. The values range between 1 - 'no tension' and 3 - 'a lot of tension.' The mean values and confidence intervals show that perceptions of tension are significantly lower in the social democratic countries by comparison to the other groups in the first three figures but not in the fourth.

\section{Figure 11 Perceived Tension between Rich and Poor $(1-$ no tension; 3 - a lot of tension)}

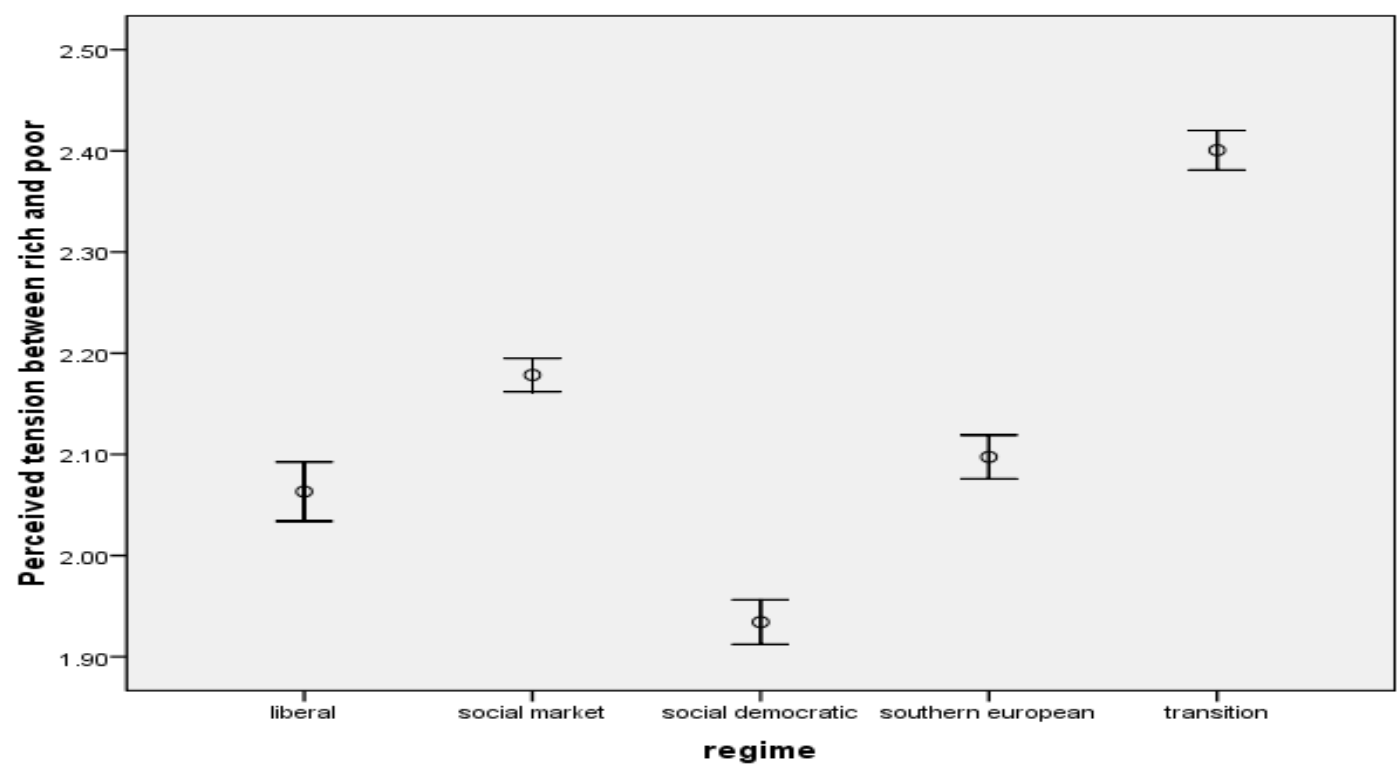

Source: Euro barometer 72.1 (Sept-Oct 2009). See notes for Figure 2.

Figure 11 shows that tensions between the rich and poor are perceived to be highest in the transition and social market countries but substantially lower in the Nordic countries. Figure 12 again shows that perceptions of tensions between managers and workers are highest in the social market group of countries, southern Europe and in the transition group (eastern Europe). They are somewhat lower in the liberal group and substantially lower in the social democratic group. The perception of tensions between generations (Figure 13) is also highest in the transition countries and lowest in the social democratic group, with the liberal

\footnotetext{
${ }^{7}$ The EB asked the following question: "In all countries there sometimes exists tension between social groups. In your opinion, how much tension is there between each of the following groups in [COUNTRY]?" [1 no tension; 2 some tension; 3 a lot of tension]
} 
Figure 12 Perceived Tension between Managers and Workers by Regime

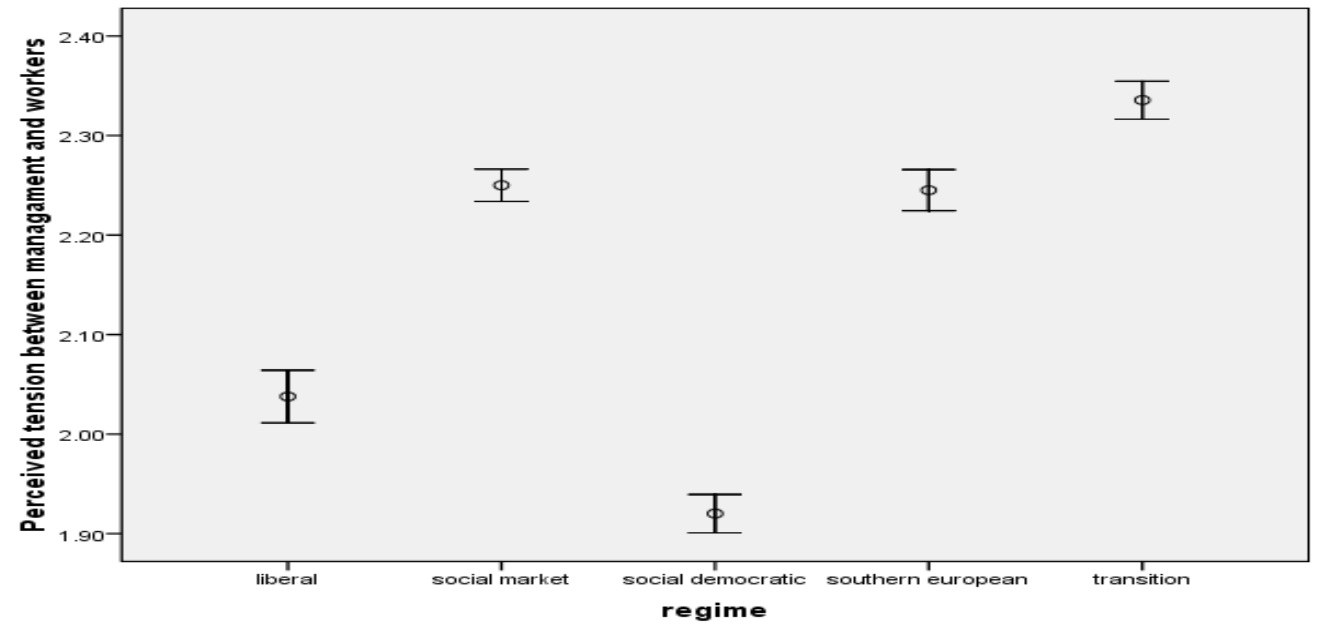

Source: Eurobarometer 72.1 (Sept-Oct 2009). See notes for Figure 2.

\section{Figure 13 Perceived Tension between Young and Old by Regime}

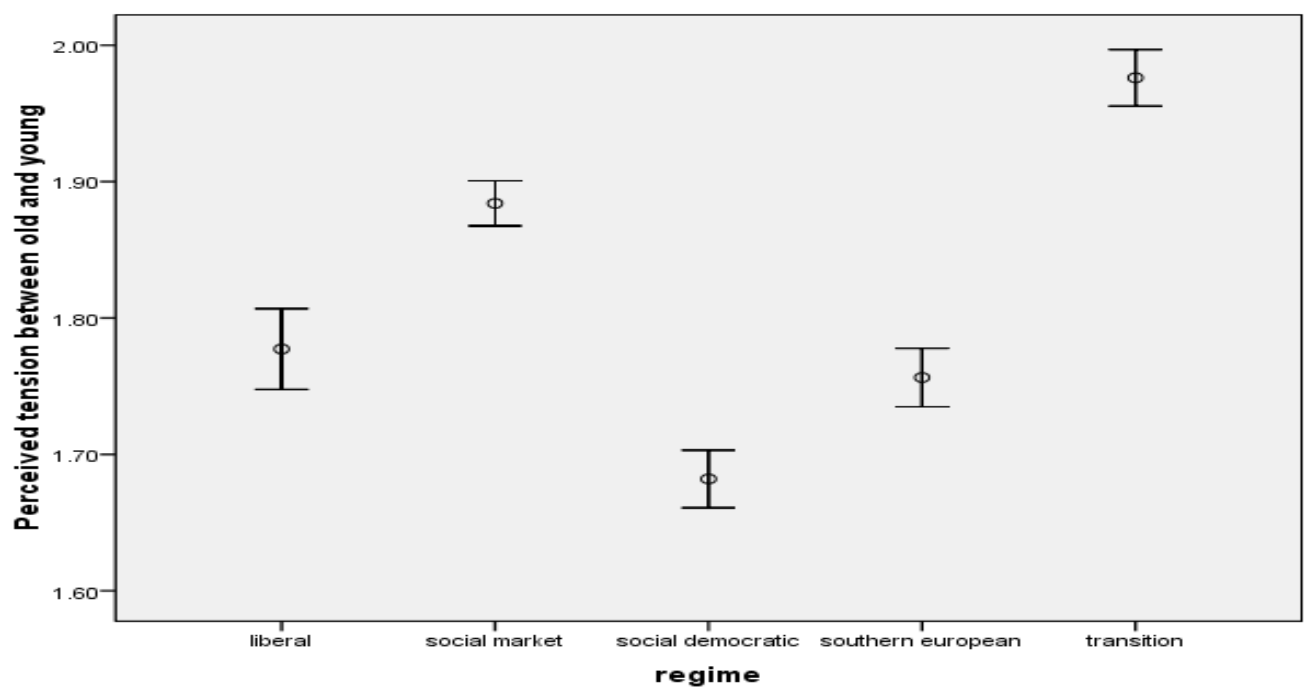

Source: Eurobarometer 72.1 (Sept-Oct 2009). See notes for Figure 2. 


\section{Figure 14 Perceived Tension between Different Ethnic Groups by Regime}

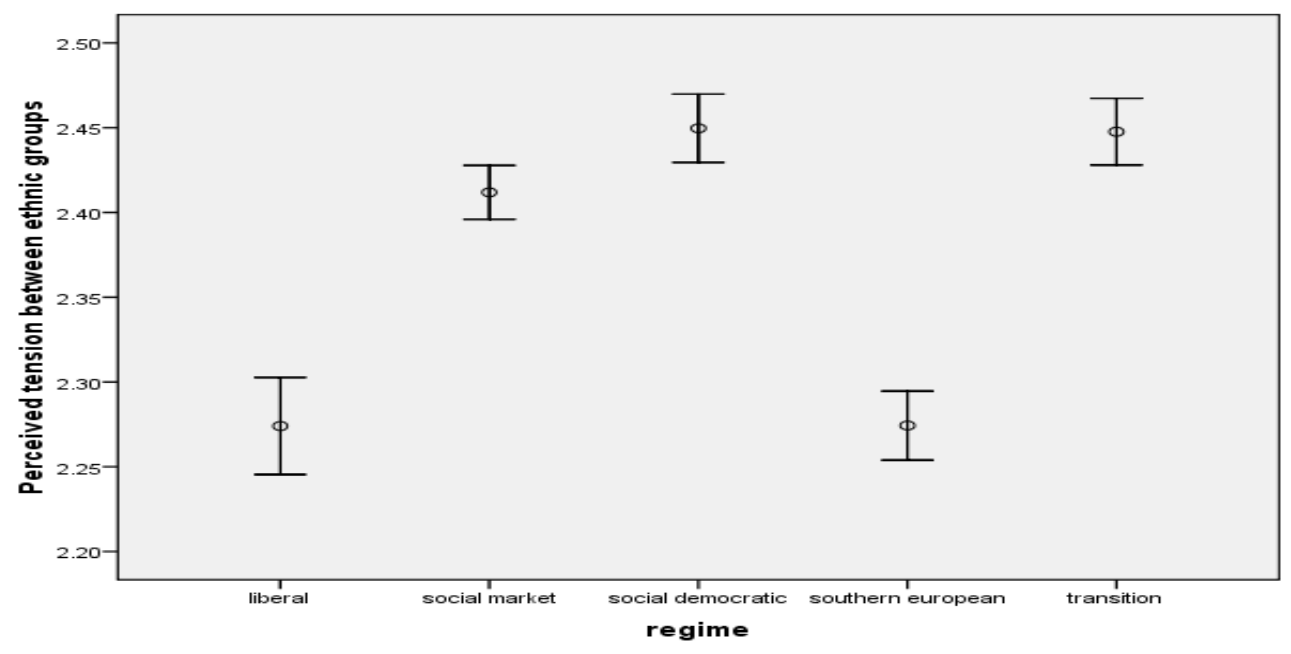

Source: Eurobarometer 72.1 (Sept-Oct 2009). See notes for Figure 2.

When it comes to perceptions of tension between ethnic groups (Figure 14), however, the social democratic group tops the ranking order, along with the transition countries. The social market group follows shortly after. Levels of perceived tensions between ethnic groups are relatively low in the liberal and southern European countries.

On three of the four measures of perceived conflict, then, the Nordic countries again show themselves to be quite distinctive. The social democratic regime appears to have maintained greater solidarity than the others between social classes and generations. However, this is not extended to ethnic groups.

\section{The Decline of Social Cohesion and the Nordic Exception.}

The major theories of social change identify powerful forces which undermine social cohesion in modern developed societies. Globalisation, increasing social inequality and generational division, and the proliferation of individualism and identity politics, all, it is argued, portend an ongoing fracturing of society and the weakening of collective social bonds. Trends on some of the key measures of social cohesion, analysed above, generally support this contention. Trust in others, trust in parliament and tolerance of immigrants all appear to be in decline in most regions of the developed world. With the social effects of the global recession still unfolding, it is likely that other measures of social conflict and division, 
such as industrial conflict and civil unrest, will also be on the rise. However, our analysis suggests that this is not an entirely convergent trend. In one region at least, social cohesion appears to have been sustained, if not strengthened. The Nordic countries seem to be substantially more trusting and slightly more tolerant than they were 30 years ago. Perceptions of conflicts between social groups and generations seem also to be lower in this region than elsewhere. How can we explain this apparent exceptionalism?

Scholars and commentators have given most attention to the question of trust - the area where Nordic exceptionalism is most pronounced. Popular wisdom has it that small and homogenous societies are more likely to be trusting and that we should not therefore be surprised that the Nordic countries have a greater propensity towards trusting than other more populous and more diverse societies. Statistical analysis only partially supports this explanation, however. In cross-country analysis population size and density do not correlate with levels of social trust (Delhey and Newton, 2005). Some less populous countries, like Denmark, do have high levels of trust. Others, like Portugal, do not. Conversely, some very populous countries, like Brazil, have very low levels of trust, whereas others, like Japan and Canada, are amongst the most trusting. Analyses of the relations between ethnic and cultural diversity and trust have also to date produced rather contradictory results. In a series of crossnational and cross-area analyses, Alesina and Ferrara (2003), Knack and Keefer (1997), Putnam (2000, 2007), Uslaner (2002) and Helliwell (2003) all find that increasing diversity reduces average levels of trust. Putnam claims, in his analyses across areas in the US (Putnam, 2007), that diversity reduces trust both within and across groups, even when we control for other factors, such as income inequality. However, other studies, using appropriate controls, have found no relation between diversity and trust, either at the cross-national level (Green, Preston and Janmaat, 2006; Hooghe et al, 2009) or in cross-area analyses in Canada (Johnson and Soroka, 1999) and the UK (Lekti, 2006).

One of the most exhaustive analyses of trust and diversity, which explicitly seeks to provide an explanation of Nordic exceptionalism, is the study by Delhey and Newton (2005). In an analysis of 55 countries with data from the World Values Survey, they find that high trust societies are generally: wealthy, egalitarian, well-governed, protestant and relatively homogenous. Even when the Nordic countries are removed from the sample, these correlations remain significant, although they are weaker. Delhey and Newton (2005) claim that Protestantism and ethnic fractionalisation together explain 46 per cent of the variance in 
trust across countries. However, as they admit, when you control for good governance and social spending, the significance of these factors declines markedly.

The explanations of Nordic exceptionalism based on cultural homogeneity in cross-sectional analyses are somewhat inconclusive. If you look at the trends, they appear even weaker. Nordic countries have become more trusting over a period when they have become substantially more diverse. Immigrants in Denmark were only 3.1 percent of the population in 1980 but 10.6 percent in 2009. In Sweden the proportion rose from four percent of the population in 1960 to 13.8 percent in 2009 (Larsen, 2009). By 2008, 18 percent of the Swedish population had foreign origins (nine percent if you exclude Finns) and 14 percent were foreign-born. Sweden has a higher proportion of people of migrant stock than all but eight of the 26 OECD countries for which we have data - higher than France, Germany and the UK. Yet it ranked second highest on levels of trust (1999 wave) - far higher than other less diverse societies.

The most convincing explanations of Nordic exceptionalism seem to relate to the fundamental characteristics of social democracy. Nordic countries are substantially more egalitarian than most developed countries. Despite small rises in household income inequality in the past two decades, Nordic countries remain the most income-equal in the developed world, and substantially more equal as a group than any of the other groups (see Figure 15). They also have the most universalistic welfare states.

\section{Figure 15 Trends in Income Inequality (OECD gini)}

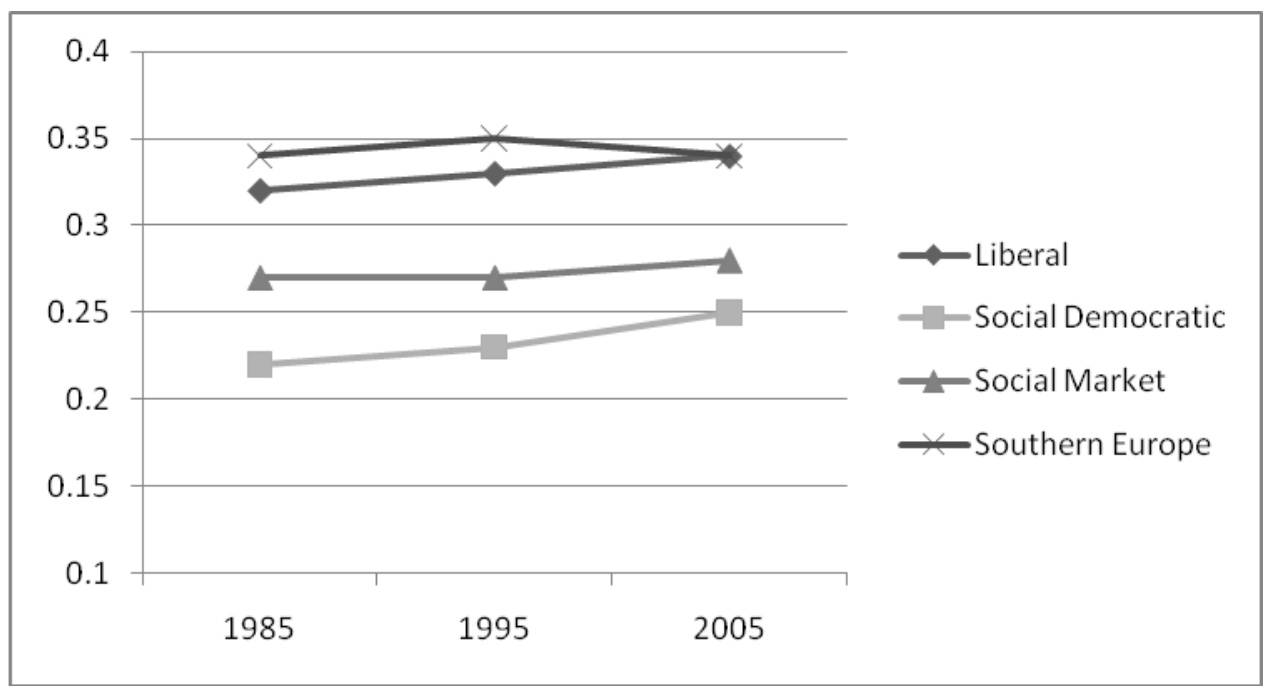

Source: OECD (2010). http://stats.oecd.org/Index.aspx?DatasetCode=INEQUALITY 
As we have seen, many cross-national studies of trust find a positive relationship to egalitarianism (Green, Preston and Janmaat, 2006; Uslaner, 2003). As Uslaner has argued, relative equality promotes solidarity because people feel more or less in the same boat. Inequality increases the social and cultural distance between groups and makes trusting more difficult. Likewise, universalistic welfare systems, because they include everyone on the same terms, promote the sense of solidarity and connectedness between social groups. Indeed, they also depend on it since such welfare systems can rarely be won politically if such solidarity does not exist. This creates a circular, mutually reinforcing syndrome of social responsibility which makes trusting more likely. It also promotes trust in the political system which is seen to help everyone. A more psychological explanation of the relationship between equality and trust is also plausible. As Wilkinson argues (1996), inequality increases

high stakes competition in society which is likely, in turn, to lead to greater status anxiety and stress. Stress has been shown to underlie many manifestations of poor physical and mental health. It may also be un-conducive to trusting. It is quite possible, as our longitudinal data for the UK suggest (Table 1), that children growing up in highly stressed family environments acquire personality traits (such as anxiety, introversion and pessimism) which inhibit the development of trust. Trusting probably occurs through a combination of early childhood learning and adult experiences.

\section{Social Cohesion Regimes and the Global Economic Crisis}

The analysis, above, of key indicators of social cohesion suggest both convergence and divergence across countries and regions. There is ample evidence to suggest that overall cohesion in the advanced countries and regions in the West is in decline. However, the trends are not uniform. In the Nordic region, at least, the trends on a number of key indicators suggest a consolidation, if not strengthening, of social cohesion.

However, this approach, which compares countries along linear scales for particular indicators, only just begins to capture the complex changes in the nature of social bonding which are occurring in different societies and regions, because what holds different societies together is never identical. As we have argued elsewhere (Green and Janmaat, forthcoming) there are actually quite different historical traditions of social cohesion in the West, each based on distinctive institutional and cultural foundations. For specific historical periods, defined by relatively stable institutional and ideological conditions, we can refer to these as 
'regimes of social cohesion' where a regime is an 'ideal type' in Weber's sense of a stylised model which captures the key and defining characteristics of a particular set of actual social forms. Using statistical analysis of cross-country data on institutional and attitudinal characteristics of countries - including through cluster analysis, factor analysis and composite indicators - we can identify at least three distinctive contemporary 'regimes of social cohesion.' These are typically manifested in countries which comparative political economy identifies as 'liberal', 'social market' and 'social democratic' in their types of social and economic organisation. Arguably, each of these regimes is facing stresses and strains in the face of global trends, but each are vulnerable in different ways.

Historically, liberal societies, such as the UK and the US, have tended to see social cohesion as resting on the triple pillars of the free market, active civil society and their core beliefs in individual freedoms, opportunities and meritocratic rewards. A wider set of shared values has not been seen as essential for a cohesive society. Nor, in the UK case at least, has a strong, or tightly defined, sense of national identity and national culture been deemed as central. The role of state in welfare and re-distribution has also been played down as a pre-condition for cohesion.

The social market regime of social cohesion differs from the liberal regime in the greater emphasis placed on maintaining a wide set of shared values and active participation in national formal political activity. It also relies more on the state to generate the conditions for social cohesion through welfare and labour market institutions. The social market, it could be said, tends to institutionalise the sources of social cohesion.

The social democratic regime of social cohesion relies, like the social market regime, on solidaristic labour market organisation and generous social benefits. As in the social market regime of social cohesion it is state-led and highly institutionalised. However, the social democratic regime differs in the crucial respect that it places equality at the centre of its social philosophy. Each of these models exhibit different fault lines under the pressures of globalisation and economic crisis.

In several respects social cohesion in liberal societies should not be overly vulnerable to the forces of globalisation. Markets have become broader and more dominant under the dominant neo-liberal paradigm of globalisation. Civic association may have changed its forms but still seems relatively robust in countries like Britain and America. And without the need for a broad set of shared values, increasing social and cultural diversity should not seem such a 
threat to liberal societies. Indeed, despite racism and xenophobia persisting in some sections of societies, and despite sporadic eruptions of inter-ethnic conflict, these societies do seem to remain relatively tolerant. However, social cohesion in these societies is, arguably, under severe threat from another quarter - from the atrophy of those core beliefs which unite its citizens. As inequalities widen, opportunities diminish, and rewards appear ever more detached from effort and merit, fewer and fewer people are likely to hold to the belief that they live in an equitable, meritocratic society. If these beliefs are, indeed, the main glue which holds liberal societies together, social cohesion may be severely tested in the coming years of austerity.

In the social market economies the fault lines of social cohesion are different. The countries of north-west continental Europe, which adhere broadly to the social market socio-economic model, have sought to balance the goals of economic growth and individual opportunity with other more social goals. In this context, a period of economic stagnation perhaps comes as less of shock, particularly when the burden of belt-tightening is shared more equally. For the most part these countries are less unequal than the liberal societies and social mobility has been higher in recent years (Blanden et al. 2005). Here the strains on social cohesion appear to be coming primarily from a different quarter.

Most of these countries have historically placed a high premium on shared values and 'national' culture. In the republican tradition of France, this was based mostly on political ideals, derived from the French Enlightenment and subsequent Revolution, but also on a strong sense of identification with the French language and way of life (Brubaker, 1992). Historically, in Germany, and in the countries proximate to it, excepting perhaps Holland, ethno-cultural identity tended to prevail over state identity, since nationalism arose before territorially secure sovereign states were established, and when the nation and state could not easily be made to coincide (Kohn, 2008). In the post-war years a more civic identity has emerged but a broad set of common values and beliefs still tend to be important, in a way that they are not in the UK. The problem for these countries is that these identities are now challenged by rising social and ethnic diversity and by increasing value pluralism (see Green and Janmaat, forthcoming). This is where social cohesion appears to be most vulnerable.

The Nordic countries are widely considered to be amongst the most socially cohesive in the world. On most of the usual measures of social cohesion they score highly relative to other countries. Social trust and political trust have both been far higher within the social 
democratic Nordic countries than in social market and liberal countries since the 1980s. Levels of violent crime are generally lower, although Finland differs from the other Nordics in having quite high homicide rates. People in Nordic countries perceive less tension between rich and poor, workers and managers and between the generations than in the other country groups. Perceptions of tensions between ethnic groups are relatively high but on one measure at least - the proportion saying they have no problem with having immigrants as neighbours - Nordic countries are on average more tolerant than countries in the other groups. What is more, while other country groups show declines over recent decades on key indicators of social cohesion, the Nordics post substantial rises. Social trust and political trust were considerably higher in 2005 than in 1981. People in the Nordic countries seem to have become more tolerant during the 1990s and are probably still more tolerant than they were in 1981. But the Nordic countries also face threats to their strongly solidaristic cultures.

The main challenge to social cohesion in the Nordic states comes from the long-term pressures on public spending and thus on the welfare state. Generous welfare provision is a key part of the social contract between the state and its citizens in Nordic countries and people are willing to pay the necessary price (in taxes) for this. However, demographic change and global economic forces make the contract ever harder to sustain. Mounting global economic competition places pressure on all states to constrain public spending so that taxation does not rise to levels which would deter foreign investors and undermine market confidence. Population ageing in the Nordic countries, as elsewhere, raises the costs of the welfare state, particularly in health and pension costs. So far the Nordic countries have resisted abandoning their welfare model. After its banking crisis, Sweden was forced to rein in public spending in the 1990s, although not to a point which put its welfare system in jeopardy. A degree of privatisation was allowed which curtailed, to a small degree, the universality of provision. Other countries have trimmed spending in certain areas. But generally electors in Nordic countries have continued to support high taxes for their welfare systems.

However, tensions clearly exist around immigration and its associated social costs which have periodically flared up into political controversy. Can the social contract around taxes and welfare be maintained with the additional social costs associated with rising immigration? Is the native population willing to extend its solidarity to immigrants? 
The issue has been particularly acute in countries like Denmark whose immigration policies were traditionally based more on humanitarian than skills-related criteria and which consequently had high rates of unemployment amongst immigrant groups, with substantial associated social costs. It was opposition in Denmark to the Social Democrats' open-door immigration policies, which saw 60 percent of asylum applications granted in the late 1990s, which fuelled the rise of the far-right Danish People's Party in the early 2000s. This party joined the Conservatives and Radical Liberals in a new coalition Government in 2001 and this coalition government then passed some of Europe's strictest immigration laws in 2002. (BBC News, February 19 $\left.{ }^{\text {th }}, 2005\right)$. Sweden's Social Democrat government castigated the Danish Government for undermining Scandinavian solidarity, as Denmark's share of successful asylum applications to Scandinavian countries dropped from 31 percent in 2001 to 9 percent in 2003, while Sweden's rose from 41 to 60 percent. Sweden, meanwhile, with a more skills-based immigration policy, passed new laws in 2008 making it easier for skilled European migrants to obtain work permits.

The immigration debate in the Scandinavian countries well illustrates the social democratic dilemma of how to maintain humanitarian immigration policies at the same time as providing generous welfare. Whether the adoption of more economically viable, skill-based immigration policies will settle the issue remains to be seen. In any event, it would seem that the immigration issue defines the limits of social solidarity in the social democratic regime. Social cohesion in the Nordic countries is based on a social contract which operates within national borders. If globalisation were to erode state sovereignty to the point where such national contracts were no longer viable, it too would be vulnerable, even in Scandinavia. 


\section{References}

Alesina, A. and La Ferrara, E. (2002) 'Who Trusts Others?' Journal of Public Economics, 85, pp.207234.

Almond, G.A. and Verba, A.(1963). The Civic Culture.Princeton University Press, Princeton, N. J.

BBC News (2005) Denmark's Immigration Issue, $19^{\text {th }}$ February: at: http://news.bbc.co.uk/1/hi/4276963.stm Accessed 25.7.2010.

Beck, U. (1999) What Is Globalization? Polity Press, Cambridge.

Beck, U. (2004) Ulrich Beck - Johannes Wills: Conversations with Ulrich Beck. Polity Press, Cambridge.

Blandon, J., Gregg, P. and Machine, S. (2005) Intergenerational Mobility in Europe and North America: A Report Supported by the Sutton Trust. Centre for Economic Performance, London School of Economics, London.

Brubaker, R. (1992) Citizenship and Nationhood in France and Germany. Harvard University Press, Boston.

Canovan, M. (1996) Nationalism and Political Theory. Edward Elgar, Cheltenham.

Castells, M. (1997) The Power of Identity. The Information Age: Economy, Society and Culture, Vol 11. Blackwell, Oxford.

Deary, I. J., Batty, G. D., and Gale, C. R. (2008). 'Bright Children Become Enlightened Adults', Psychological Science, 19, pp. 1-6.

Delhey, J. and Newton, K. (2005) 'Predicting Cross-National Levels of Social Trust: Global Pattern or Nordic Exceptionalism?' European Sociological Review, pp. 331-327.

Dorling, D. (2009) Injustice: Why Social Inequality Persists. Policy Press, Bristol.

Durkheim, E. (1964) The Division of Labour in Society. Translated by G. Simpson. The Free Press, New York.

Esping-Andersen, G. (2005) 'Inequality of Incomes and Opportunities' in A. Giddens and P. Diamond (eds) The New Egalitarianism. Polity Press, Cambridge.

Green, A. and Janmaat J.- G. (forthcoming) Regimes of Social Cohesion: Societies and the Crisis of Globalisation. Palgrave, London.

Green, A., Janmaat, J-G. and Han, C. (2009) Regimes of Social Cohesion, LLAKES Research Paper 1, Institute of Education, London.

Green, A., Preston, J. and Janmaat, G. (2006) Education, Equality and Social Cohesion. Palgrave, Basingstoke.

Giddens, A. (1991) Modernity and Self-Identity. Self and Society in the Late Modern Age. Polity, Cambridge.

Hall, P. (1999) 'Social Capital in Britain.' British Journal of Policy, 29, pp.417-461.

Hall, P. and Soskice, D. (eds) (2001) Varieties of Capitalism: The Institutional Foundations of Comparative Advantage. Oxford University Press, Oxford.

Helliwell, J. (2003) 'How's Life? Combining Individual and National Variables to Explain Subjective Well-Being.' Economic Modelling, 20, 2, pp.331-360.

Hooghe, M., Reeskens, T., Stolle, D., and Trappers, A. (2009) 'Ethnic Diversity and Generalized Trust in Europe. A Cross-National Multilevel Study.' Comparative Political Studies, 42(2), pp. 198223.

Hutton, W. (2002) The World We're In. Little, Brown, London. 
Inglehart, R. (1997). Modernization and Postmodernization. Princeton University Press, Princeton, N.J.

Johnson, R and Soroka, S (1999) 'Social Capital in a Multicultural Society: the Case of Canada', paper presented at the Annual Meeting of the Political Science Association, Sherbrooke QC.

Kohn, H. (2008) The Idea of Nationalism: A Study in its Origins and Background. Transaction Publishers, New Brunswick.

Knack, S. and Keefer, P. (1997) 'Does Social Capital Have an Economic Pay-off? A Cross-Country Investigation.' Quarterly Journal of Economics, CX11, pp.1251-1288.

Larsen, C. (2009) 'Why Social Cohesion Declines in Liberal Regimes and Increases in Social Democratic Regimes.' Paper for RC 19 Montreal Conference, Aarlborg University.

Letki, N. (2006) 'Does Diversity Erode Social Cohesion? Social Capital and Race in British Neighbourhoods.' Unpublished paper, Nuffield College, Oxford.

Martin, H. P. and Schumann, H. (1996) The Global Trap. Zed Books, London.

Newton, K. (1999) 'Social and Political Trust in Established Democracies,' in P. Norris (ed) Critical Citizens. Oxford University Press, Oxford.

North, A. (1990) 'A Transaction Theory of Politics, Journal of Theoretical Politics, 2, pp.355-356.

Osberg, L. (ed) (2003) The Economic Implications of Social Cohesion. Toronto University Press, Toronto.

Putnam, R. (2000) Bowling Alone: The Collapse and Revival of American Community. Simon and Schuster, New York.

Putnam, R (2007) 'E Pluribus Unum: Diversity and Community in the Twenty-First Century.' Scandinavian Political Studies, 20, pp.139-174.

Reich, R. (2001) The Future of Success. Alfred A. Knopf, New York.

Reeskens, T. (2007) 'Defining Social Cohesion in Diverse Societies.' Paper presented at the $103^{\text {rd }}$ Annual Meeting of the American Political Science Association, Chicago, August 30-Septemeber $2^{\text {nd }}$, 2007.

Schoon, I., Cheng, H. (in press) 'Determinants of Political Trust: A Life Time Learning Model.' Journal of Developmental Psychology.

Schoon, I., Cheng, H., Gale, C.R., Batty, D. and Deary, I.J. (2010). 'Social Status, Cognitive Ability, and Educational Attainment as Predictors of Liberal Social Attitudes and Political Trust,' Intelligence, 38, 144-150.

Sturgis, P., Read, S., and Allum, N. (2010) 'Does Intelligence Foster Generalized Trust? An Empirical Test Using the UK Birth Cohort Studies', Intelligence, 38, pp. 45-54.

Stiglitz, J. (2004) The Roaring Nineties. Penguin Books, London.

Stiglitz, J. (2010) Freefall: Free Markets and the Sinking of the World Economy, Penguin books, London.

Touraine, A. (2000) Can We Live Together? Polity Press, Cambridge.

Thurow, L. (1996) The Future of Capitalism. Nicholas Brealey Publishing, London.

Uslaner, E. (2002) The Moral Foundations of Trust. Paper for the Symposium, "Trust in the Knowledge Society," University of Jyvaskyla, Jyvaskala, Finland, 20 September, 2002, Department of Government and Politics, University of Maryland.

Wade, R. (2001) 'Winners and Losers: the Global Distribution of Income is Becoming More Unequal: That Should be a Matter of Greater Concern Than it is.' The Economist, 359 (8219). pp. 93-97. 
Wilkinson, R. (1996) Unhealthy Societies: The Affluence of Inequality. Routledge, London.

Wilkinson, R. and Pickett, K. (2009) The Spirit Level: Why More Equal Societies Almost always Do Better. Allen Lane, London

Willetts, D. (2010) The Pinch: How the Baby Boomers Took Their Children's Future - and Why They Should Give It Back, Atlantic Books, London. 